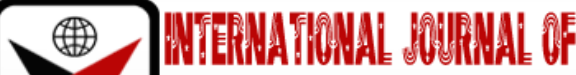

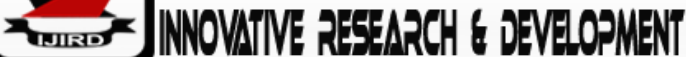

ISSN 2278-0211 (Online)

\section{Study of Thin-Layer Drying Kinetics of Fermented Cocoa Beans (Theobroma Cacao L) Using Semi-Empirical Models: Determination of Effective Moisture Diffusivity and Activation Energy}

\begin{tabular}{c} 
Jean Benjamin Bidias \\
\hline \hline $\begin{array}{c}\text { Maroua, University of Maroua, Cameroon } \\
\text { Guy Bertrand Tchaya }\end{array}$ \\
Eecturer, Department of Renewable Energy, National Advanced School of Engineering of \\
Engineering of Maroua, University of Maroua, Cameroon \\
Ghislain Arnaud Mouthé Anombogo \\
Engineering of Maroua, University of Maroua, Cameroon \\
Chrisdel Chancelice Ndjeumi \\
Senior Lecturer, Department of Environmental Sciences, National Advanced School of \\
Engineering of Maroua, University of Maroua, Cameroon \\
Djomdi \\
Enior Lecturer, Department of Environmental Sciences, National Advanced School of \\
Senior Lecturer, Department of Renewable Energy, National Advanced School of \\
Jean Luc Nsouandélé \\
Associate Professor, Department of Renewable Energy, National Advanced School of \\
Engineering of Maroua University of Maroua, Cameroon
\end{tabular}

\begin{abstract}
:
This study is all about of cocoa beans moisture content behavior and prediction, during drying and experimental determination of effective moisture diffusivity and activation energy of thin-layer. Experiments were carried out on fermented cocoa beans using an oven at 40, 45, 50, 55 and $60^{\circ} \mathrm{C}$. Seven semi-empirical models based on the drying kinetics were used for the modeling. This work determined the effective moisture diffusivities and activation energy of cocoa beans using respectively a variable diffusivity model based on Fick's second diffusion law and Arrhenius standard equation. The aim was to obtain the evolution of moisture content in cocoa beans considering temperature, moisture content ratio and time. The results revealed and demonstrated the reliability of some theoretical models with natural drying for temperatures below $45^{\circ} \mathrm{C}$ and others with convective hot-air drying for temperatures above $50^{\circ} \mathrm{C}$. All of these models seemed to be the most appropriate for describing the type of drying of cocoa beans. Values of the apparent diffusion coefficient are between $2.33275 \times 10^{-11} \mathrm{~m}^{2} / \mathrm{s}$ and $2.8561 \times 10^{-11} \mathrm{~m}^{2} / \mathrm{s}$. The effective moisture diffusivity increases as a function of the drying temperature and decreases as a function of the decrease in moisture content of the product. Values of Do and Ea were estimated respectively as $1.2310^{-6} \mathrm{~m}^{2} / \mathrm{s}$ and $43.56 \mathrm{~kJ} / \mathrm{mol}$ respectively, in accordance with material and literature. It was observed that, $p H$ values of different cocoa beans samples were between $4.82 \pm 0.26$ and $5.43 \pm 0.41$.
\end{abstract}

Keywords: Drying kinetics, thin-layer models, effective moisture diffusivity, Activation energy, $\mathrm{pH}$, Cocoa beans

\section{Introduction}

Several products of the food industry, cosmetics and pharmaceuticals are cocoa beans (Theobroma cacao L.) raw materials. Post-harvest processes of cocoa bean have an influence on the quality of the products; these depend very much on the stage of drying. So, famers are more and more interested in the future of their production and manufacturers are bent at the preparation of their raw material [1]. This opportunity requires the mastery of the techniques of drying and conservation of the product.

Today, the industry requires that its products always have the same characteristics. It is then essential to know the temperature and the distribution of moisture content of the product in order to complete the drying process [2, 3]. For 
this reason, the knowledge of the evolution of effective moisture diffusivity and activation energy are necessary in order to control the quality of cocoa beans and to facilitate their conservation $[4,5]$.

Recently, determination of the effective moisture diffusivity and activation energy of cocoa beans have been carried out by several researchers, who have determined it through numerical simulation, and experimentation. Most of the works used an evaluation process based on Fick's law, the diffusion of matter through cocoa bean, in hygroscopic domain, is supposed to obey [6-9].

The aim of this research is the evaluation of effective moisture diffusivity in Cameroonian cocoa bean according to moisture content, temperature and drying time by applying analytical solution of Fick's law.

\section{Material and Methods}

\subsection{Material}

Sartorius brand electronic precision balance is used for the various weighing of samples with a mass of less than $300 \mathrm{~g}$. Its measurement reading precision is \pm 0.01 gram with a stability time of 1.5 seconds. A Memmert brand dehydration oven (figure 1) operating by forced convection in the temperature range of 30 to $250^{\circ} \mathrm{C}$ were used. The oven with several trays has internal dimension of $17 \mathrm{~cm} \times 22 \mathrm{~cm} \times 37 \mathrm{~cm}$ with an accuracy variation of $\pm 1^{\circ} \mathrm{C}$ for drying. Samples of cocoa beans fermented under banana leaves for six (6) days were from the harvest of producers in Kiki, a village located in the Centre Region of Cameroon. Used samples have a spherical shape $[6,8,9]$.

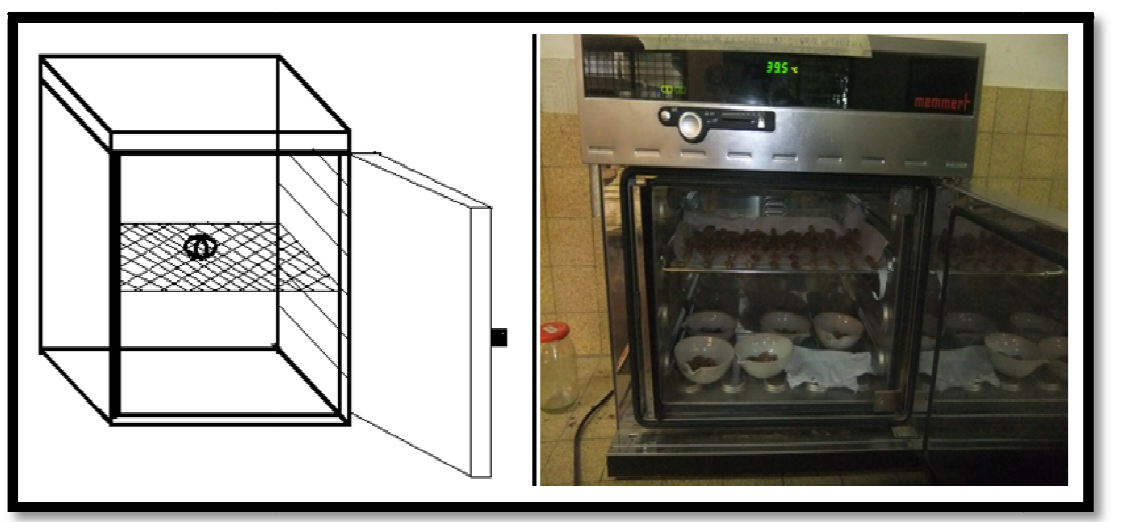

Figure 1: Experimental Device for the Determination of Desorption Isotherms

\subsection{Methods}

\subsection{Experimental Protocol}

Samples were examined in daylight according to the cross-section color of cocoa beans, meaning all brown, partially purple-brown. As per the standard, beans with more than $60 \%$ fully brown color were considered good to flavor beans (Figure 1). The test was performed in triplicate [10,11].Dehydration process (2-hour intervals) of each sample using the $0.01 \mathrm{~g}$ precision balance was recorded.

These samples undergo a second operation to obtain the anhydrous mass (Ms) by setting the oven at $103^{\circ} \mathrm{C}[6$, 12]. Samples were regularly weighed until there no more variation in mass. From this obtained parameter, different moisture contents at equilibrium were defined, obtained by desorption isotherms $[13,14,15]$.

\section{2. $p H$ Determination}

Experimental treatments were replicated three times.Ground nibs (5g) were homogenized in $45 \mathrm{ml}$ boiled distilled water. The mixture was filtered with Whatman No. 4 filter paper and cooled in a temperature range of $20-25{ }^{\circ} \mathrm{C}$. Filtrate was measured using a pH meter which had been calibrated with buffers at $\mathrm{pH} 4$ and 7.Experimental data were analyzed using one-way ANOVA and mean comparison using Duncan's Multiple Range Test at 93\% confidence level [5, 11, and 39].

\subsection{Drying Kinetic Modeling}

In order to interpret resulting experimental points, seven (7) literature described models were used for the adjustment and modeling (Table 1) [6,15-20].

\begin{tabular}{|c|c|c|}
\hline Model & Model Equation & References \\
\hline Newton & $X r=\exp (-k t)$ & {$[4-9,21]$.} \\
\hline Henderson et Pabis & $X r=a \exp (-k t)$ & {$[4,9,22]$.} \\
\hline Page & $X r=a \exp \left(-k t^{n}\right)$ & {$[9,18,23,24]$.} \\
& & \\
\hline
\end{tabular}




\begin{tabular}{|c|c|c|}
\hline Model & Model Equation & References \\
\hline Hii et al & $X r=a \exp \left(-k t^{n}\right)+c \exp \left(-g t^{n}\right)$ & {$[6,9]$.} \\
\hline Logarithmic & $X r=a \exp (-k t)+c$ & {$[9,25]$.} \\
\hline Midilli-Kucuk & $X r=a \exp \left(-k t^{n}\right)+b t$ & {$[9,26]$.} \\
\hline Verma et al. & $X r=a \exp (-k t)+(1-a) \exp (-g t)$ & {$[7,24,27]$.} \\
\hline
\end{tabular}

Table 1: Mathematical Models Used For Modeling

Constants $\mathrm{a}, \mathrm{b}, \mathrm{c}, \mathrm{k}, \mathrm{g}$, and $\mathrm{n}$ were determined through the modelling of experimental points by theoretical mathematical models for the considered experiment and by minimizing the sum of the Root Mean Square Error (1) of water contents, [28].

Root Mean Square Error $R M S E=\left[\frac{1}{N} \sum_{1}^{N}\left(X r_{\text {pre }, i}-X r_{\text {exp }, i}\right)^{2}\right]^{1 / 2}$

$X r_{\exp , i} i^{i \grave{e m e}}:$ Equilibrium experimental water content (\% ms: dry matter),

$X r_{\mathrm{pre,i}} i^{i \text { ème }}$ : Predicted equilibrium water content (\% ms), N: Number of experimental points. To assess the degree of reliability of each model to explain experimental isotherms, mean relative error in percent given by equation (1) is used. This error on each cocoa bean is evaluated on all obtained experimental points at studied temperatures.

\subsection{Calculation of Effective Moisture Diffusivity C}

Experimental method based on Fick's second law is used for the determination of cocoa beans diffusivity coefficient. It is more interested in homogeneous materials such as cocoa beans, in which the heterogeneity of the material is taken into account through the use of efficient diffusivity of the water content. The other reason requires more frequently to describe moisture transfer, for biological species during shorter drying times [4-10]. This Fick diffusion law for spherical geometry is defined as follows (2):

$\frac{\partial X r}{\partial t}=D_{e f f}\left(\frac{\partial^{2} X r}{\partial r^{2}}+\frac{2}{r} \frac{\partial X r}{\partial r}\right)$

$r$ is the radial coordinate, $D_{\text {eff }}$ is the effective moisture diffusivity, and $X r$ is the ratio moisture content, defined by equation (3) $[6-9,31]$ :

$X r=\frac{X-X e q}{X o-X e q}$

$X o$ and $X e q$ represent respectively initial and equilibrium moisture content of cocoa beans.

$X$ is water content at a given time, expressed by the mathematical relation (4):

$X=\frac{M-M s}{M s}$

And $X_{e q}$ the equilibrium moisture content of cocoa beans obtained through desorption isotherms [32,33]. Moisture content at equilibrium of dried product is calculated by relation (5) [34-36]:

$X_{e q}=\frac{M_{e q}-M_{s}}{M_{s}}$

$X_{e q}:$ Moistue content at equilibrium in \%,

$M_{e q}:$ Equilibrium mass of tested cocoa bean, in g,

$M_{s}$ : Anhydrous mass of tested cocoa bean, in $\mathrm{g}$.

Using the appropriate initial and limiting conditions, Crank and al., [37] gave the analytical solution for spherical geometry by mathematical relation (6) as follows $[9,37,38]$ :

$X r=\frac{6}{\pi^{2}} \sum_{n=1}^{\infty} \frac{1}{n^{2}} \exp \left[-D e f f\left(\frac{n \pi}{R p}\right)^{2} t\right]$

Deff is the effective moisture diffusivity $\left(\mathrm{m}^{2} \mathrm{~s}^{-1}\right), \mathrm{t}$ is the drying time $(\mathrm{s}) R p$ is half the thickness of the cocoa beans at time zero ( $R p=0.012 \mathrm{~m})$. The initial and boundary conditions are as follows:

$X r=X o, 0 \leq r \leq R p$ à $t=0$ 
$X r=X e q, r=R p$ à $t \succ 0$

$\frac{\partial X r}{\partial t}=0, r=0$ à $t \succ 0$

$R p$ is the radius of the cocoa beans.

Only the first term of Equation(7) can be used to estimate the effective moisture diffusivity for long drying times [38, 39]:

$X r \cong \frac{6}{\pi^{2}} \exp \left(-D e f f\left(\frac{n \pi}{R p}\right)^{2} t\right)$

This equation was applied, assuming one-dimensional moisture diffusion and constant effective diffusivity, regardless of sample shrinkage or increase, uniform moisture distribution, and negligible external resistance. The effective moisture diffusivity is calculated using equation (8), i.e., when the curve corresponding to the natural logarithm of $\mathrm{Xr}$ is plotted against time, a line with a slope $\mathrm{K}$ is obtained:

$$
\begin{aligned}
& \ln (X r)=\ln \left(\frac{6}{\pi^{2}}\right)-\text { Deff }\left(\frac{\pi}{R p}\right)^{2} t \\
& K=\left(\frac{\pi}{R p}\right)^{2} \text { Deff }
\end{aligned}
$$

\subsection{Calculation of Activation Energy}

Activation energy is the needed energy to trigger the phenomenon of mass diffusion in agricultural products. The dependence of effective moisture diffusivity ( Deff ) on temperature is often described by the Arrhenius standard equation given by the following expression $[10,40]$ :

$D e f f=D o \exp \left(-\frac{E a}{R(T+273,15)}\right)$

$D o=$ Pre-exponential factor of Arrhenius equation $\left(\mathrm{m}^{2} / \mathrm{s}\right)$

$E a=$ Activation energy $(\mathrm{kJ} / \mathrm{mol})$

$T=$ drying air temperature $\left({ }^{\circ} \mathrm{C}\right)$

$R=$ ideal gas constant $(8.314 \mathrm{~J} / \mathrm{mol} \cdot \mathrm{K})$

Activation energy $(E a)$ is calculated from the slope of equation (11); that is, when the curve corresponding to the natural logarithm of $D_{\text {eff }}$ is plotted against the inverse of the temperature $(1 / T)$, a line with a slope $K_{1}$ is obtained $[10,38,39]$.

$$
\ln (\text { Deff })=-\frac{E a}{R(T+273,15)}+\ln (D o)
$$

\subsection{Statistical Analysis}

To assess degree of reliability of each model to explain the drying of cocoa beans, statistical parameters such as chi-square $\chi^{2}(12)$, mean squared error MSE and regression ratio $\left(\mathrm{R}^{2}\right)$ were used for quality of fit.

Regression analysis was performed, using the nonlinear GRG solver algorithm. The best model is the one which has the greatest value of $\mathrm{R}^{2}$ close to 1 , the smallest values of $\chi^{2}$ and $\operatorname{RMSE}[3,29]$.

$\chi^{2}=\frac{\sum_{i=1}^{N}\left(X r_{\text {exp }, i}-X r_{p r e, i}\right)^{2}}{N-z}$

$N=$ Number of experimental points,

$\mathrm{d}_{f}=$ degree of freedom of regression model;

$\mathrm{d}_{f}=N-z:$ Number of variables of each model.

$\mathrm{R}^{2}$ was calculated as follows:

$$
R^{2}=\frac{(\operatorname{cov}(X r \exp , i ; \text { Xrpre }, i))^{2}}{S_{r \exp , i}^{2} \times S_{r \text { pre }, i}^{2}}
$$

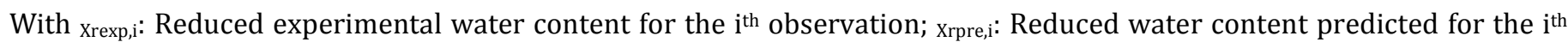
observation; Cov (Xrexp,i; Xrpre,i): Covariance of Xrexp,i and Xrpre,i; Srexp,i: Standard deviation of Xrexp,I; Srpre,i: Standard deviation of Xrpre, $i \mathrm{~N}$ : Number of observations; $\mathrm{n}$ : Number of coefficients in the model. Calculations of $\mathrm{r}$, RME (Relative Mean Error) values enabled to appreciate and classify the different models [3,28,30]. 


\section{Results and Discussion}

\subsection{Experimental Results}

The drying kinetics of the convective hot-air dried cocoa beans inside the oven are as shown in Figure. 2. Initial moisture content before drying was about 66\%. As expected, drying temperatures had a significant effect on the drying kinetics of the samples. The moisture content continuously decreased with time. An increase in temperature resulted in different final moisture contents and imposes different reduced drying time.

For the $52 \mathrm{~h}$ drying, values of the moisture content of $12.76 \%$ at the temperature of $40^{\circ} \mathrm{C}$ and $09.63 \%$ at the temperature of $60^{\circ} \mathrm{C}$ are obtained. The moisture content curves during drying showed a decreasing trend beyond the moisture content of $66 \%$, at drying temperatures of $40,4550,55$ and $60^{\circ} \mathrm{C}$.

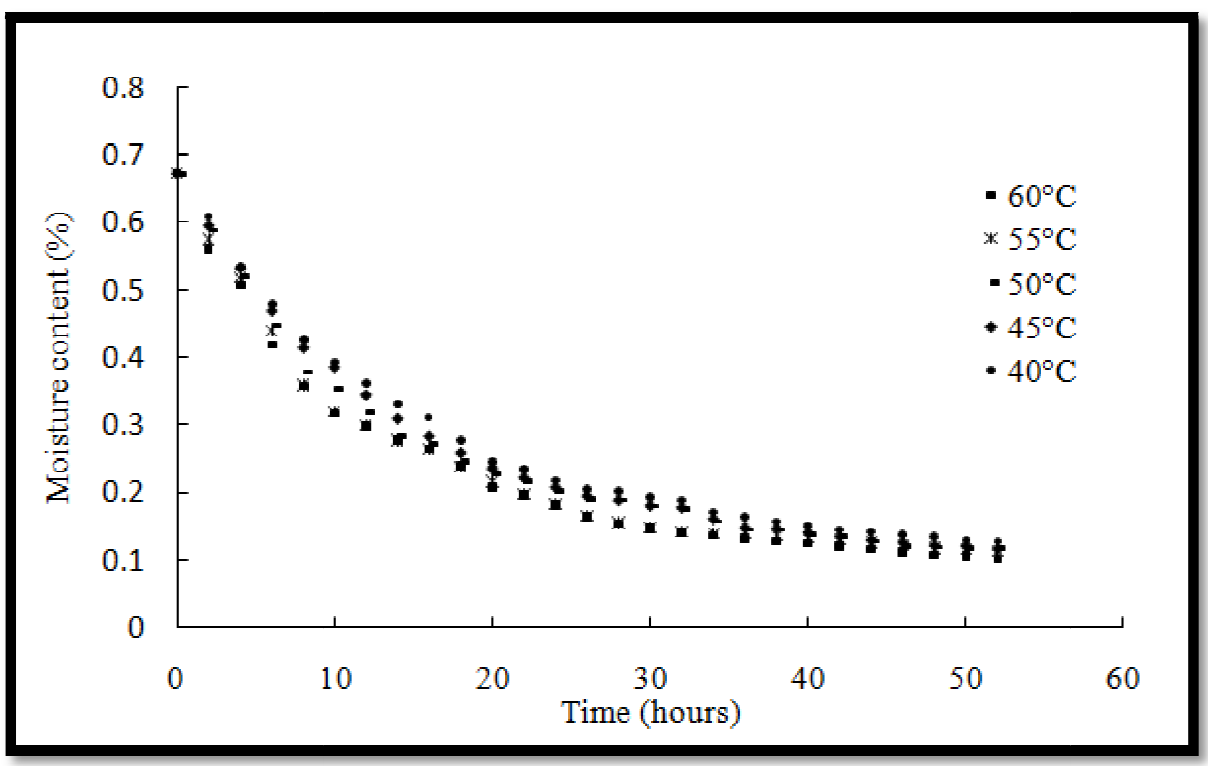

Figure 2:Moisture Content of Cocoa Beans as a Function of Drying Time at Different Temperatures

The experimental points of reduced moisture contents of fermented cocoa beans samples as a function of the drying time for five temperatures studied $40,45,50,55$ and $60^{\circ} \mathrm{C}$ are shown in the Figure 3 . It can be seen that at these different temperatures, reduced moisture content has the same appearance of decreasing exponential form.

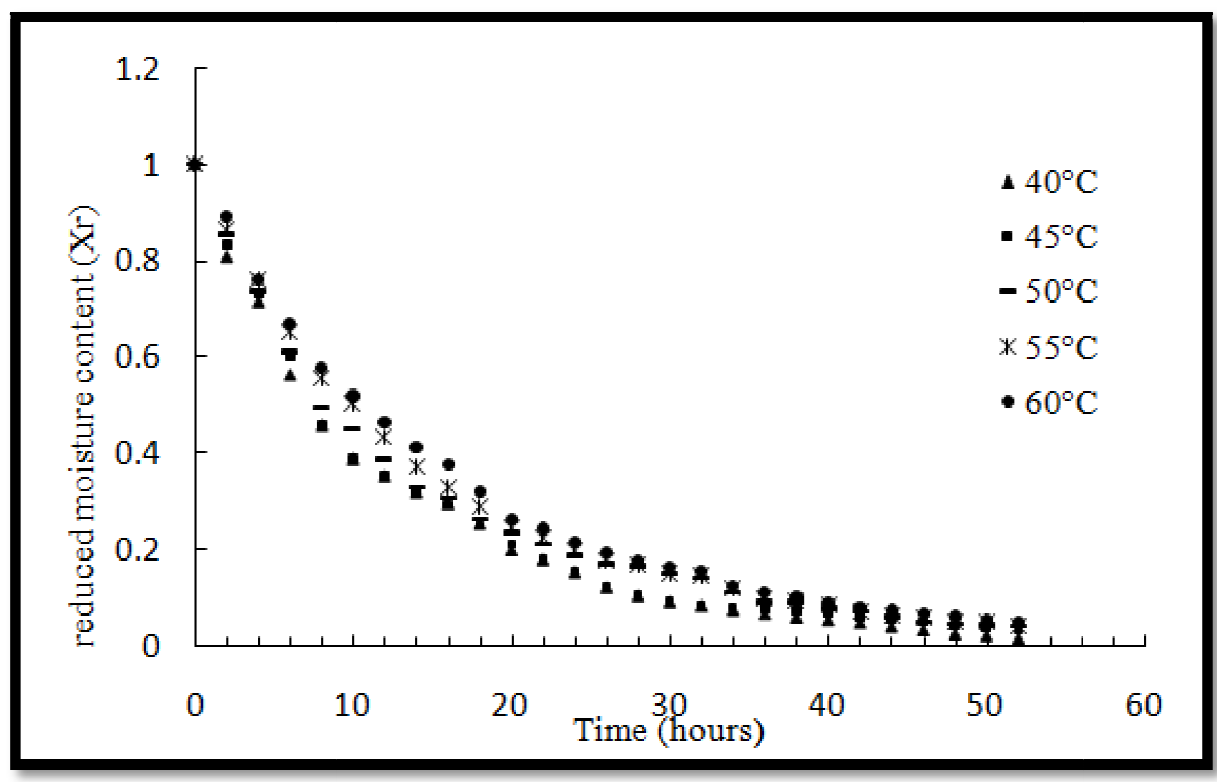

Figure 3: Moisture Content of Cocoa Beans as a Function of Drying Time for Different at Temperatures

The analysis of Figure 3 also shows out that increasing temperature leads to a respective reduction in drying time. Therefore, this work contributes to the improvement of drying models to better predict the evolution of cocoa beans moisture content as function of drying time and temperature. 
These reduced moisture content of cocoa beans samples require and oblige to improve appropriate models of drying processes at different temperatures. Among the most used models, are Newton, Henderson and Pabis, Page, Hii et al., Logarithmic, Midilli - Kucuk, Verma et al. models. Parameters a, b, c, k, g, and n, optimize the smoothing of experimental points for most agrifood products in areas of water activity. From the experimental results, determination of the parameters based on an appropriate estimation method is made for a better appreciation.

\subsection{Estimation of the Parameters of the Curves of the Different Models}

Table 2 shows the values obtained for the parameters of mathematical drying models. This table shows the values of the correlation ratio $\mathrm{R}^{2}$, of $\chi^{2}$ and of RMSE corresponding to the different models. An increase in the values of parameters models is observed with the increase in temperature for Newton, Henderson and Pabis models. A variation composed of a decrease and an increase in parameters of, Page, Hiiet al., Midilli - Kucuk and Verma et al. Logarithmic models is reported with increasing temperature.

The greater moisture diffusivity at this stage results to most moisture reduction during the tempering period. The best model describing the thin film drying characteristic was chosen as the one with the highest $\mathrm{R}^{2}$ values, the lowest $\chi^{2}$ and lowest RMSE values. In overall, the range of values $\mathrm{R}^{2}, \chi^{2}$ and RMSE are included, respectively in the intervals of 0.9462 to 0.9887, of 0.0017 to 0.0178 and of 0.0309 to 0.1153 (Table 2).

For the five temperatures $\left(40,45,50,55\right.$ and $\left.60^{\circ} \mathrm{C}\right)$ Newton, Page, Henderson and Pabis models have the best estimation errors $\mathrm{R}^{2}, \chi^{2}$ and RMSE at 40 and $45^{\circ} \mathrm{C}$. Hii et al, of Midilli - Kucuk and of Verma et al Logarithmic models show better values of the estimation errors $\mathrm{R}^{2}, \chi^{2}$ and RMSE for temperatures of 50,55 and $60^{\circ} \mathrm{C}$. It appears from Table 2 that the drying models simultaneously take into account the product to be dried and the drying temperature. This study reveals and shows Newton, Page and Henderson and Pabis models adequacy to natural drying, more precisely for temperatures below $45^{\circ} \mathrm{C}$. Hii et al, Midilli - Kucuk and Verma et al models are reliable for convective hot-air drying, more precisely for temperatures above $50^{\circ} \mathrm{C}$. All of these models seem to be the most appropriate to describe of cocoa beans drying kinetic.

\subsection{DryingKinetics of Cocoa Beans}

Figures 4, 5, 6, 7 and 8 show experimental points for reduced moisture content of samples. Figures (a) present theoretical curves of drying models at different temperatures $40,45,50,55,60^{\circ} \mathrm{C}$ as function of time. Curves corresponding to natural logarithm of reduced moisture content as function of time are shown in Figure (b).

Figures 4a, 5a, 6a, 7a, and 8a are illustrated by experimental values of reduced moisture content and the predicted values of Newton, Henderson and Pabis, Page, Hii et al, Logarithmic, Midilli - Kucuk, Verma et al. drying models at different temperatures and drying time. These models curve look the same as experimental points and all describe the drying process. Those of Newton, Henderson and Pabis and Page have almost identical results as the experiment in accordance with literature [4]. But there is a slight difference between experimental and predicted data during at $40^{\circ} \mathrm{C}$ (Figure 4a). As far as experimentations followed at $45,50,55,60^{\circ} \mathrm{C}$ respectively Figures $5 \mathrm{a}, 6 \mathrm{a}, 7 \mathrm{a}$, and $8 \mathrm{a}$ concerned, their theoretical kinetic graphics are closer to the experimentation ones. A very small deviation is observed only at $40^{\circ} \mathrm{C}$. It emerges from that, Hii et al, of Midilli - Kucuk and of Verma et al Logarithmic models are obeying the drying process for temperature higher than $45^{\circ} \mathrm{C}$. as confirmed by other authors [6, 7, and 9].

Deviation observed at $40^{\circ} \mathrm{C}$ is due to the inclusion of the tempering period which creates a discontinuity in the drying curve due to the lack of heating. Nevertheless, the application of semi-theoretical models to describe the kinetics of combined drying-tempering process has already been reported by researchers [41-47].

Figures $4 b, 5 b, 6 b, 7 b$, and $8 b$ show respectively for temperatures of $40,45,50,55$ and $60^{\circ} \mathrm{C}$, the comparison of the experimental values corresponding to the logarithm of reduced moisture content and their regression line with respect to time. All of these figures show straight lines with slopes K obtained and used for the evaluation of the effective moisture diffusivity. The values of $\mathrm{R}^{2}$ obtained 0.9971 (figure 4b), 0, 9959 (figure 5b), 0.9926 (figure 6b), 0.9812 (figure 7b), and 0.9948 (figure $8 \mathrm{~b}$ ) are close to 1 and show the regression ability to correctly determine the effective moisture diffusivity during cocoa beans drying process.

\begin{tabular}{|c|c|c|c|c|c|}
\hline Model & Temperature & Coefficients and Constants & $\mathbf{R}^{2}$ & $\chi^{2}$ & $\boldsymbol{R M S E}$ \\
\hline \multirow{4}{*}{ Newton } & $40^{\circ} \mathrm{C}$ & $k=0,056243$ & 0,9921 & 0,0037 & 0,0315 \\
\cline { 2 - 6 } & $45^{\circ} \mathrm{C}$ & $k=0,065386$ & 0,9918 & 0,0035 & 0,0242 \\
\cline { 2 - 6 } & $50^{\circ} \mathrm{C}$ & $k=0,073386$, & 0,9819 & 0,0061 & 0,0314 \\
\cline { 2 - 6 } & $55^{\circ} \mathrm{C}$ & $k=0,079481$ & 0,9912 & 0,0038 & 0,0241 \\
\cline { 2 - 6 } & $60^{\circ} \mathrm{C}$ & $k=0,082386$ & 0,9808 & 0,0039 & 0,0246 \\
\hline \multirow{4}{*}{$\begin{array}{c}\text { Henderson et } \\
\text { Pabis }\end{array}$} & $40^{\circ} \mathrm{C}$ & $a=0,999982, k=0,062243$ & 0,9923 & 0,0017 & 0,0215 \\
\cline { 2 - 6 } & $45^{\circ} \mathrm{C}$ & $a=0,99992, k=0,072241$ & 0,9937 & 0,0019 & 0,0224 \\
\cline { 2 - 6 } & $50^{\circ} \mathrm{C}$ & $a=0,999682, k=0,080243$ & 0,9747 & 0,0075 & 0,0314 \\
\cline { 2 - 6 } & $55^{\circ} \mathrm{C}$ & $a=0,989452, k=0,086243$ & 0,9861 & 0,0062 & 0,0211 \\
\hline
\end{tabular}




\begin{tabular}{|c|c|c|c|c|c|}
\hline & $60^{\circ} \mathrm{C}$ & $a=0,997682, k=0,091243$ & 0,9885 & 0,0068 & 0,0208 \\
\hline Model & Temperature & Coefficients and Constants & $\mathbf{R}^{2}$ & $\chi^{2}$ & RMSE \\
\hline \multirow{5}{*}{ Page } & $40^{\circ} \mathrm{C}$ & $k=0,104967, n=0,825418$ & 0,9862 & 0,0024 & 0,0380 \\
\hline & $45^{\circ} \mathrm{C}$ & $k=0,125067, n=0,795418$ & 0,9814 & 0,0022 & 0,0375 \\
\hline & $50^{\circ} \mathrm{C}$ & $k=0,148067, n=0,745418$ & 0,9865 & 0,0024 & 0,0378 \\
\hline & $55^{\circ} \mathrm{C}$ & $k=0,154067, n=0,735418$ & 0,9732 & 0,0091 & 0,0874 \\
\hline & $60^{\circ} \mathrm{C}$ & $k=0,158067, n=0,745418$ & 0,9697 & 0,0042 & 0,0581 \\
\hline \multirow{5}{*}{ Hii et al } & $40^{\circ} \mathrm{C}$ & $\begin{array}{c}a=0,52002, k=0,072361 c=0,480051 \\
g=0,002186 n=1,817112\end{array}$ & 0,9675 & 0,0088 & 0,0589 \\
\hline & $45^{\circ} \mathrm{C}$ & $\begin{array}{c}a=0,53002, k=0,069361 \\
c=0,470051 g=0,002086 \\
n=1,827112\end{array}$ & 0,9815 & 0,0035 & 0,0387 \\
\hline & $50^{\circ} \mathrm{C}$ & $\begin{array}{c}a=0,54582, k=0,069361 c=0,470051 \\
g=0,002186 n=1,817112\end{array}$ & 0,9649 & 0,0093 & 0,0593 \\
\hline & $55^{\circ} \mathrm{C}$ & $\begin{array}{c}a=0,55002, k=0,072361 c=0,441051 \\
g=0,002186 n=1,817112\end{array}$ & 0,9743 & 0,0079 & 0,0463 \\
\hline & $60^{\circ} \mathrm{C}$ & $\begin{array}{c}a=0,56002, k=0,072361 c=0,440051 \\
g=0,002186 n=1,817112\end{array}$ & 0,9638 & 0,0091 & 0,0599 \\
\hline \multirow{5}{*}{ Logarithmic } & $40^{\circ} \mathrm{C}$ & $a=0,9220012, k=0,0998 c=0,082583$ & 0,9637 & 0,0089 & 0,0531 \\
\hline & $45^{\circ} \mathrm{C}$ & $a=0,9792112, k=0,090289 c=0,034999$ & 0,9698 & 0,0075 & 0,0683 \\
\hline & $50^{\circ} \mathrm{C}$ & $a=0,8700112, k=0,09995 c=0,076583$ & 0,9619 & 0,0042 & 0,0585 \\
\hline & $55^{\circ} \mathrm{C}$ & $a=0,8980112, k=0,10995 c=0,075183$ & 0,9854 & 0,0031 & 0,0482 \\
\hline & $60^{\circ} \mathrm{C}$ & $a=0,9000112, k=0,10995 c=0,074583$ & 0,9632 & 0,0088 & 0,0541 \\
\hline \multirow{5}{*}{ Midilli-Kucuk } & $40^{\circ} \mathrm{C}$ & $\begin{array}{c}a=1,006874 k=0,163383 b=0,00026 \\
n=0,707331\end{array}$ & 0.9785 & 0,0083 & 0,0512 \\
\hline & $45^{\circ} \mathrm{C}$ & $\begin{aligned} a=1,006474 k & =0,170383 b=0,00036 \\
n & =0,707341\end{aligned}$ & 0,9612 & 0,0044 & 0,0588 \\
\hline & $50^{\circ} \mathrm{C}$ & $\begin{aligned} a=1,005474 k & =0,173383 b=0,00025 \\
n & =0,707341\end{aligned}$ & 0,9873 & 0,0035 & 0,0437 \\
\hline & $55^{\circ} \mathrm{C}$ & $\begin{aligned} a=1,005074 k & =0,174383 b=0,00035 \\
n & =0,707321\end{aligned}$ & 0,9846 & 0,0033 & 0,0441 \\
\hline & $60^{\circ} \mathrm{C}$ & $\begin{array}{c}a=1,004874 k=0,174583 b=0,00036 \\
n=0,707131\end{array}$ & 0,9641 & 0,0049 & 0,0782 \\
\hline \multirow{5}{*}{ Verma et al. } & $40^{\circ} \mathrm{C}$ & $a=0,443208 k=0,237069 g=0,045492$ & 0,9637 & 0,0054 & 0,0421 \\
\hline & $45^{\circ} \mathrm{C}$ & $a=0,393208 k=0,223069 g=0,045492$ & 0,9837 & 0,0042 & 0,0328 \\
\hline & $50^{\circ} \mathrm{C}$ & $a=0,453208 k=0,237069 g=0,045492$ & 0,9637 & 0,0057 & 0,0434 \\
\hline & $55^{\circ} \mathrm{C}$ & $a=0,441208 k=0,227069 g=0,045489$ & 0,9784 & 0,0045 & 0,0389 \\
\hline & $60^{\circ} \mathrm{C}$ & $a=0,443204 k=0,237068 g=0,045492$ & 0,9697 & 0,0056 & 0,0432 \\
\hline
\end{tabular}

Table 2: Values of Estimated Parameters and Statistical Selection Criteria 




Figure 4: Evolution of Reduced Moisture Content Vs Time at $40{ }^{\circ} \mathrm{C}$ of Cocoa Beans: (A) Kinetic Models; (B) Kinetics Linear Model



Figure 5: Evolution of Reduced Moisture Content Vs Time at $45^{\circ} \mathrm{C}$ Of Cocoa Beans: (A) Kinetic Models; (B) Kinetic Linear Models

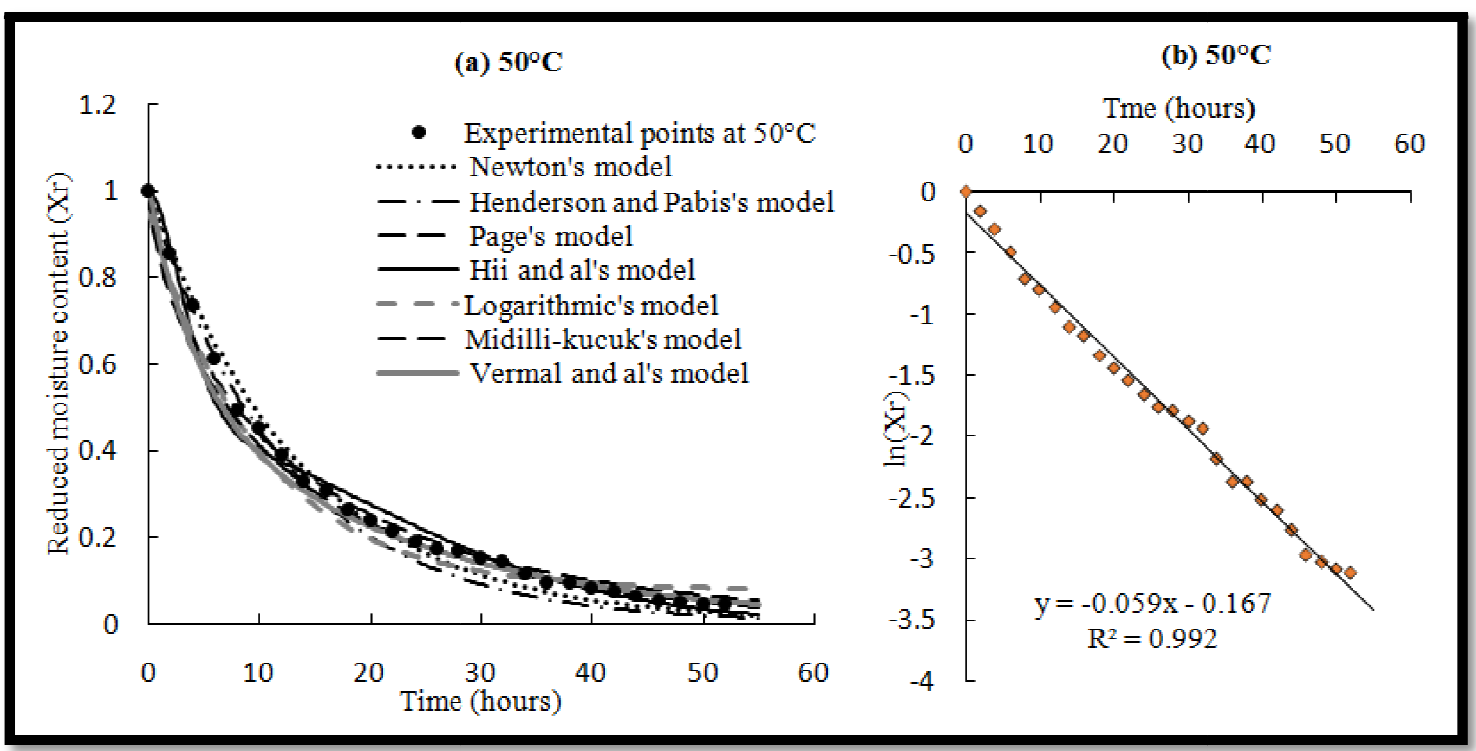

Figure 6: Evolution of Reduced Moisture Content Vs Time at $50{ }^{\circ} \mathrm{C}$ of Cocoa Beans: (A) Kinetic Models; (B) Kinetic Linear Models 




Figure 7:Evolution of Reduced Moisture Content Vs Time at $55^{\circ} \mathrm{C}$ of Cocoa Beans: (A) Kinetic Models; (B) Kinetic Linear Models

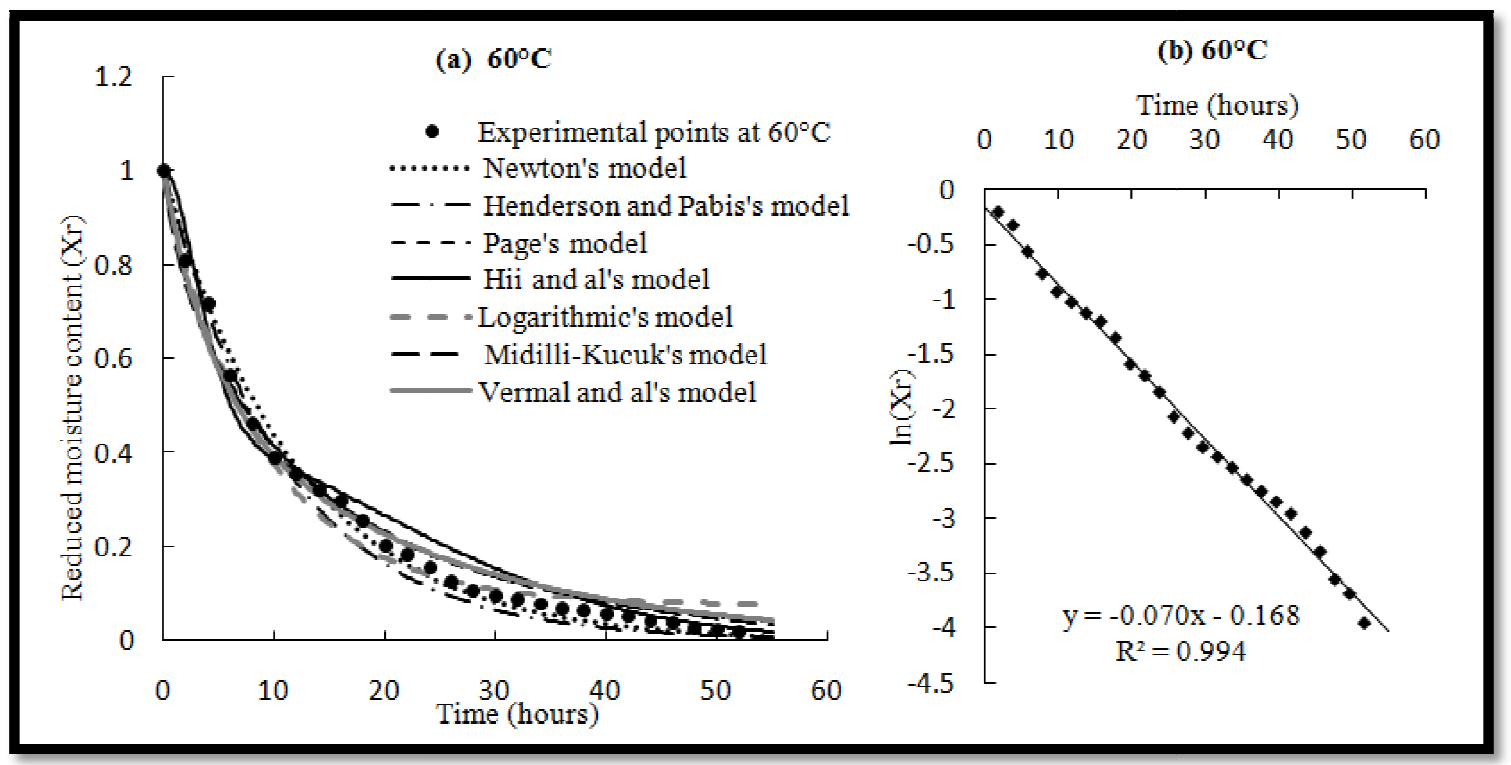

Figure 8:Evolution of Reduced Moisture Content Vs Time at $60{ }^{\circ} \mathrm{C}$ of Cocoa Beans: (A) Kinetic Models; (B) Kinetic Linear Models

Obtained results are similar to those of Akmel (2010), Hii and al (2009) Kamena (2017), Nogbou et al (2015), Mujaffar et al (2018), Blaise KamenanKoua et al (2019) considering cocoa beans drying kinetics modeling through several empirical models. This work shows that of Hii et al, Midilli - Kucuk, Verma et al logarithmic models are the most indicated for drying kinetics of coco beans, with an $\mathrm{R}^{2}$ of 0.994 and an MSE of 0.0075 at drying temperatures between $45^{\circ} \mathrm{C}$ and $60^{\circ} \mathrm{C}$, in agreement with Hii et al model who. The study claims the $40{ }^{\circ} \mathrm{C}$ to $60{ }^{\circ} \mathrm{C}$ range as the best temperature range for cocoa beans drying.

\subsection{Efficiency of Diffusion}

Effective moisture diffusivity $\left(D_{\text {eff }}\right)$ was calculated from Equation (8), using slopes derived from logarithm regression of reduced moisture content $\ln (\mathrm{Xr}$ ) (Figures $4 \mathrm{~b}, 5 \mathrm{~b}, 6 \mathrm{~b}, 7 \mathrm{~b}$, and $8 \mathrm{~b}$ ) as a function of the drying time $\mathrm{t}$ and assuming that air characteristics are constant for each test.

Estimated effective moisture diffusivity values are shown in Table 3 . The values range from $2.33 \times 10^{-11}$ to $2.85 \times 10^{-11} \mathrm{~m}^{2} / \mathrm{s}$ and are within the range of values reported in many cocoa beans drying kinetic [2, 5, 8, 9, 10, 11, and 38]. Effective moisture diffusivity increases with temperature as predicted. 


\begin{tabular}{|c|c|c|}
\hline Temperature $\left({ }^{\circ} \mathbf{C}\right)$ & Diffusion coefficient, Deff $\left.\mathbf{~ ( m}^{\mathbf{2}} \mathbf{/ s}\right)$ & References \\
\hline 40 & $2,33275 \times 10^{-11}$ & Presentwork \\
\hline 45 & $2,38955 \times 10^{-11}$ & Present work \\
\hline 50 & $2,39766 \times 10^{-11}$ & Present work \\
\hline 55 & $2,53966 \times 10^{-11}$ & Present work \\
\hline 60 & $2,8561 \times 10^{-11}$ & Presentwork \\
\hline $60^{\circ} \mathrm{C}-80$ & $7,46 \times 10^{-11}-1.8710^{-10}$ & {$[5,9]$.} \\
\hline $30^{\circ} \mathrm{C}-40$ & $3.78 \times 10^{-11}-8.76 \times 10^{-11}$ & {$[4,7]$.} \\
\hline $40^{\circ} \mathrm{C}-60$ & $2.66 \times 10^{-10}-7.30 \times 10^{-10}$ & {$[8]$.} \\
\hline $30-40$ & $5,49 \times 10^{-10}-4,26 \times 10^{-10}$ & {$[2,6]$.} \\
\hline $55-80$ & $3.62 \times 10^{-10}-9.98 \times 10^{-10}$ & {$[38]$.} \\
\hline
\end{tabular}

Table 3: Values of Estimated Parameters and Statistical Choice Criteria

From logarithmic $D_{e f f}$ drying curves, $D_{\text {eff }}$ values were obtained under different drying conditions. These results agree with that of Hii et al. and AkmelDjedjro which presented the effective moisture diffusivity in the range of 7.46 10-11 to $1.8710^{-10} \mathrm{~m}^{2} / \mathrm{s}$. They are not equally far from those of Kamenan Blaise Koua et al., and Mujaffar et al with $10 \%$ a difference using a solar dryer. Therefore, drying conditions favored faster extraction of water in cocoa beans. Relationship between effective moisture diffusivity and temperature is assumed in the Arrhenius form as in equation 10.

\subsection{Activation Energy}

Applying equation 12, the plot of $\ln ($ Deff) vs $1 / \mathrm{T}$ gives a linear curve (Figure 9). Regression between the effective moisture diffusivities and temperatures is by the way closed to $1\left(\mathrm{R}^{2}=0.9675\right)$. Activation energy and the Arrhenius constant are determined respectively from the slope and the y-intercept. The Arrhenius constant is a diffusivity constant equivalent to diffusivity at infinitely high temperature.



Figure 9:Arrhenius Relation between Effective Moisture Diffusivity Vs Temperature

Activation energy is the energy barrier that must be overcome to activate the diffusion of moisture content. When increasing temperature and therefore the drying kinetic, this energy barrier is overcome more easily. But there should be a trade-off between high temperature and acceptable product quality [48]. Too high temperature is also not recommended for drying cocoa beans due to the fact that resulting product is often associated with high acidity [49].

The values of $D o$ and $E a$ were estimated at $1.2310^{-6} \mathrm{~m}^{2} / \mathrm{s}$ and $43.56 \mathrm{~kJ} / \mathrm{mol}$, respectively. These values are within the range indicated in literature for others agricultural products (Table 4). In Hii et al. (2009) and Ndukwu et al. (2010) assumed that air characteristics is constant for each test and in accordance with the range prescribed by AkmelDjedjro (2009), Kamenan et al (2019) and Mujaffar et al. (2018) [6-9] which accounted for increased heat and mass transfer coefficients using changes in drying temperature, relative humidity and air-drying rate. These results also illustrate the range from $40^{\circ} \mathrm{C}$ to $60^{\circ} \mathrm{C}$ as best when drying cocoa beans. 


\begin{tabular}{|c|c|c|c|}
\hline Materials & Ea (kJ/mol) & $\mathbf{D}_{\mathbf{0}} \mathbf{( m}^{\mathbf{2}} \mathbf{/ s} \mathbf{)}$ & References \\
\hline Cocoa & 43.56 & $1.23 \times 10^{-6}$ & Present work \\
\hline Cocoa & 22.48 & $2.91 \times 10^{-7}$ & {$[4,7]$.} \\
\hline Cocoa & 44.92 & $8.43 \times 10^{-4}$ & $[5,9] 11]$. \\
\hline Cocoa & 39.94 & $864 \times 10^{-4}$ & {$[50]$.} \\
\hline Chestnuts & $20.46-22.58$ & $6.7 \times 10^{-6}-1.21 \times 10^{-5}$ & {$[50]$.} \\
\hline Bagasse & 19.47 & $2.43 \times 10^{-7}$ & {$[51]$.} \\
\hline Peas & 42.35 & $9.633 \times 10^{-2}$ & {$[51]$.} \\
\hline Beans & $39.47-39.41$ & $7.983 \times 10^{-3}-4.5 \times 10^{-10}$ & {$[51]$.} \\
\hline Potato & $12.32-14.34$. & $5.9 \times 10^{-7}-2,314 \times 10^{-7}$ & {$[52]$.} \\
\hline
\end{tabular}

Table 4: Values of Estimated Parameters and Statistical Choice Criteria

\section{6. $p H$}

Figure 10 presents $\mathrm{pH}$ analysis of cocoa beans. It is observed that, $\mathrm{pH}$ mean values of different samples of cocoa beans are between $4.82 \pm 0.26$ and $5.43 \pm 0.41$. Physicochemical properties obtained from cocoa beans samples showed that the $\mathrm{pH}$ is acid (4.8-5.5). Therefore, $\mathrm{pH}$ decreases during fermentation process, and then it increases during drying. Drying temperature increases when $\mathrm{pH}$ decreases. These results are confirmed by those of Hiiet al., and Kouadioet al., [11, 53]. At this $\mathrm{pH}$, cocoa beans are favorable substrate for molds replication and therefor to acidy the substrate. However, fungi can develop at pH between 3and 8 with optimum growth between 5 and 6 . Obtained results indicate that moisture ratio is high and contamination ratio increased. This is because fungi majority prefer a high moisture ratio. Drying is important to stop acidification process that starts during fermentation and allows to dry cocoa beans.

In addition, chemical processes that take place inside beans give color, taste and special scent to chocolate [40]. Reducing moisture ratio of cocoa beans to $8 \%$ is important because it helps the prevention of molds proliferation than can contaminate beans during storage.

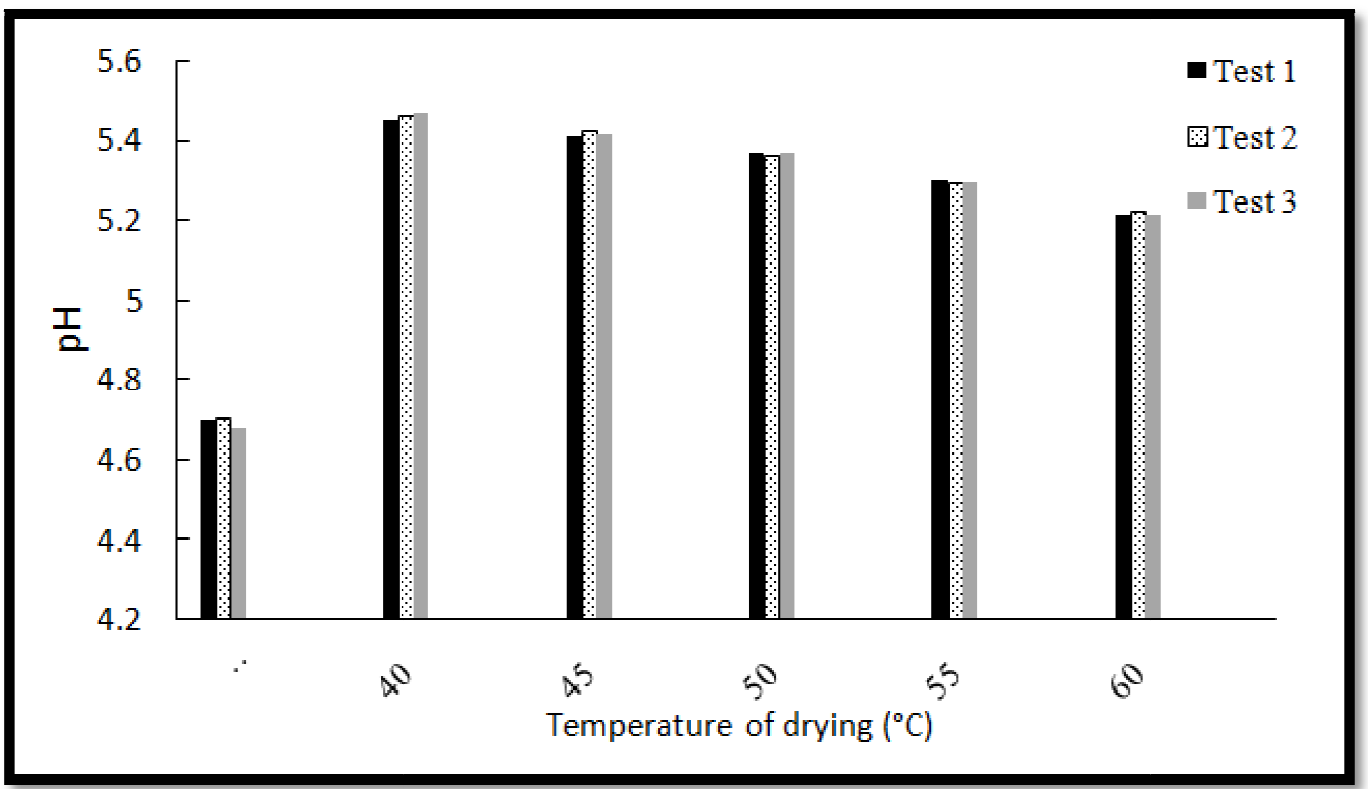

Figure 10:The Ph of Dried and Fermented Cocoa Samples

\section{Conclusion}

In this work, drying models describe the whole drying behavior of biological cocoa beans from the Centre region of Cameroon. Newton, Page, Henderson and Pabis models are appropriate when air characteristics are constant at each test with values of $\mathrm{R}^{2}$ closer to 1 , those of $\chi^{2}$ and RMSE lower whatever the temperature. of Hii et al, Midilli - Kucuk, Verma et al Logarithmic models, are suitable for drying cocoa beans taking into account the drying air temperature, relative humidity and air convection. It is then possible to assume that, for a fixed temperature, models differ according to type and drying conditions.

Values of effective moisture diffusivity are between $2.33275 \times 10^{-11} \mathrm{~m}^{2} / \mathrm{s}$ and $2.8561 \times 10^{-11} \mathrm{~m}^{2} / \mathrm{s}$. Note that effective moisture diffusivity increases as function of drying temperature and decreases as function of the decrease in moisture content of the product. These results confirm the increase in the effective moisture diffusivity with temperature according to Arrhenius equation. Values of $D o$ and $E a$ are estimated at $1.2310^{-6} \mathrm{~m}^{2} / \mathrm{s}$ and $43.56 \mathrm{~kJ} / \mathrm{mol} \mathrm{respectively}$ and are in accordance with literature.

\section{References}


i. Michel Barel, (2013), Qualité du cacao L'impact du traitement post-récolte, Éditions Quæ RD 10, 78026 Versailles Cedex, France.

ii. B. K. Kamenan, P. M. Ekoun, P.Gbaha, (2017) Séchage des fèves de cacao dans un séchoir solaire indirect à circulation forcée d'air,Revue CAMES Science Appliquée et de l' l'ingénieur vol. 2 no. 2, pp. 15-19.L. I. Nogbou,D. C. Akmel, K. Brou, N. E Assidjo, (2015) Modélisation de la cinétique de séchage des fèves de cacao par des modèles semi-empiriques et par un réseau de neurones artificiels récurrent: cas du séchage microonde par intermittence,European Scientific Journalvol. 11, pp. 1857 - 7881

iii. D. C Akmel, (2010) Séchage solaire des fèves de cacao : étude expérimentale et modélisation de la cinétique de séchage,Thèse de doctorat en Sciences et Technologies des Aliments, Université d'abobo-Adjamé, Abidjan, Cote d'Ivoire.

iv. C.L. Hii, Abdul Rahman, R. S. Jinap, Y.B. Che Man, (2006) Quality of cocoa beans dried using a direct solar dryer at different loadings,Journal of the Science of Food and Agriculture vol. 86 no. 8, pp. 1237-1243.

$v$. B. K. Kamenan, P. M. Ekoun, P. Gbaha, (2019) Evolution of shrinkage, real density, porosity, heat and mass transfer coefficients during indirect solar drying of cocoa beans, Journal of the Saudi Society of Agricultural Sciences vol. 18, pp. 72-82.

vi. D. C. Akmel, N. E. Assidjo, P. Kouamé, K. B. Yao, (2009) Mathematical Modelling of Sun Drying Kinetics of Thin Layer Cocoa Beans,Journal of Applied Sciences Research, vol. 5, no. 9: pp. 1110-1116

vii. S. Mujaffar, A. Ramroop; D.Sukha, (2018) Thin layer drying behaviour of fermented cocoa (Theobroma cacao L.) beans,21st International Drying Symposium València, Spain:pp.11-14.

viii. C.L. Hii , C.L. Law and M. Cloke,(2009) Determination of Effective Diffusivity of Cocoa Beans using Variable Diffusivity Model,Journal of Applied Sciences, vol. 9, no. 17, pp. 3116-3120

ix. L. A. Domínguez-Pérez , I. C. Brindis , L. M. L. Gálvez , J. B. Fernández , F. J. M. Rocha 3 and P. G. Alamilla, (2019) Kinetic Studies and Moisture Diffusivity During Cocoa Bean Roasting, Processes, vol. 7, no.770, pp. 1-12.

$x$. C.L. Hii, C.L. Law, M. Cloke, (2009)Modeling using a new thin layer drying model and product quality of cocoa,Journal of Food Engineering, vol. 90, pp 191-198Talla, J. R. Puiggali, W. Jomaa, Y. Jannot, 'Shrinkage and density evolution during drying of tropical fruits: application to banana,' J. Food Eng. Vol. 64, pp. 103-109, 2004.

xi. K. E. Kakou, D. C. Akmel, V AbouoN'Guessan, E AssidjoNogbou, L. S Niamké(2015) Isothermed'adsorptiond'eau des fèves de cacao (Theobroma Cacao L.) marchand,Europe. Scientific Journal, vol. 11, no 12,pp. 355-370

xii. P. G. Alamilla, L. M. Gálvez, J. B. Fernández, and R. G. Alamilla, (2017) Physicochemical Changes of Cocoa Beans during Roasting Process,Hindawi Journal of Food Quality, pp.1-11

xiii. C. Ahouannou, Y. Jannot, E. Sanya, G. Degan, (2010) Détermination expérimentale et modélisation des isothermes de désorption de produits agricoles tropicaux,' Afrique Science.vol. 6, pp. 1-17

xiv. D. Karidioula, D. C. Akmel, N. E. Assidjo, A. Trokourey, (2018) Modélisation du séchage solaire de fèves de cacao par le Réseau de Neurones Artificiel,International Journal Biological and Chemical. Sciences, vol. 12, no.1, pp. 195202

xv. D.I. Onwude, N. Hashim, R.B. Janius, N.M. Nawi, K. Abdan, (2016) Modeling the Thin-Layer Drying of Fruits and Vegetables,' A Review. Compr. Rev. Food Sci. Food Saf. Vol. 15, pp. 599-618.

xvi. V.T. Karathanos, (1999) Determination of water content of dried fruits by drying kinetics,'Journal of Food Engineering, vol. 39, pp. 337-344.

xvii. K. Oteng-Gyang, (1982) Introduction à la microbiologie alimentaire dans les pays chauds,Technique et Documentation (Lavoisier), pp. 52-63

xviii. J. Nganhou, D. Lecomte, , P. Durmargue,.(1992) Heat and mass transfer through a thick bed of cocoa beans under stationary and transient inlet conditions,'In: Drying'92; Elsevier Science Publishers Ltd.: Essex, England, pp. 15141523.Ayensu, (1997) Dehydration of food crops using a solar dryer with convective heat flow,'Solar Energy vol. 59, pp. 121-126.

xix. E.K. Akpinar, Y. Bicer, C. Yildiz, (2003) Thin layer drying of red pepper,Journal of Food Engineering vol. 59, pp. 99104.

xx. Q. Zhang, J.B. Litchfield, (1991) An optimization of intermittent corn drying in a laboratory scale thin layer dryier, Dry Technol, vol.9, pp.383-395.

xxi. A.S. Kassem, (1998) Comparative studies on thin layer drying models for wheat,'In $13^{\text {th }}$ International Congress on Agricultural Engineering, 6: 2-6 February, Morocco.

xxii. O. Yaldiz, C. Ertekin, H.B. Uzun, (2001) Mathematical modelling of thin layer solar drying of sultana grapes,Energy vol. 26, pp. 457-465.Midilli, H. Kucuk, Z. Yapar, (2002) A new model for single layer drying, Drying Technology vol. 20, no. 7, pp. 1503-1513.

xxiii. L.R. Verma, R.A. Bucklin, J.B. Endan, F.T. Wratten, (1985) Effects of drying air parameters on rice drying models,Transactions of the ASAE 28, pp. 296-301.

xxiv. J. Trignan, (1991) Probabilités statistiques et leurs applications,Breal.

xxv. D. J. L. Wen Sun Woods, (1994) The selection of isotherm equations for wheat based on the fitting of available data,J. stored Prod. Res, vol. 30, pp. 27-43.Benhamou, M. Kouhila, B. Zeghmati, B. Benyoucef, (2010) Modélisation des isothermes de sorption des feuilles de marjolaine,Revue des Energies Renouvelables, vol. 13, no. 2, pp. 233-247.

xxvi. W. Wolf, W. E. L. Speiss\& G. Jung, (1985) Standardization of Isotherm measurements. In Properties of Water in Foods,(D. Simatos and J. L. Multon, eds.), MartinusNijhoff pub., Nertherlands. pp. 661-679.

xxvii. M. L. Medeiros, A. M. I. B. Ayrosa, R. N. M. Pitombo\& S. C. S. Lannes, (2006) Sorption isotherms of cocoa and cupuassu products,J. of Food Eng., vol. 73, pp 402-406. 
xxviii. G. H. H. Oliveira, P. C. Corrêa, E. S. Santos, P. C. Treto and M. D. M. Diniz, 'Evaluation of Thermodynamic properties using GAB model to describe the desorption process of cocoa beans,'Int. J. Food Sci. Technol., vol. 46, pp. 20772084, 2011.

xxix. A P Prette, F A C Almeida \& A Villa-Vélez (2013) Thermodynamic properties of water sorption of jackfruit (Artocarpusheterophyllus Lam.) as a function of moisture content. Food, Sci. Technol. Vol. 33, no.1, pp. $199-208$.

xxx. K. B. Koua, E. P. Koffi, P. Gbaha and S. Toure, (2014) Thermodynamic analysis of sorption isotherms of cassava (Manihotesculenta),J. Food Sci. Technol., vol. 51, no. 9, pp. 1711-1723.

xxxi. M. Kouhila, A. Belghit, M. Daguenet, et B. C. Boutaleb, (2001) Experimental determination of the sorption isotherms of mint (Menthaviridis), sage (Salvia officinalis) and verbena (Lippiacitriodora) ,Journal of Food Engineering vol. 47, pp. 281-287.

xxxii. J. Crank, (1975) The Mathematics of Diffusion,second. Clearendon Press, Oxford, UK.

xxxiii. M. C. Ndukwu, A.S. Ogunlowo, and O.J. Olukunle, (2010) Cocoa bean (theobroma cacao l.) drying kinetics,' Chilean journal of agricultural research vol. 70, no 4, pp. 633-639.

xxxiv. Y.M. Baghdadi, C.L. Hii, (2017) Mass transfer kinetics and effective diffusivities during cocoa roasting,'J. Eng.Sci. Technol., vol. 12, pp. 127-137.

xxxv. W.R Wang Daud, M.Z. MeorTalib, M. K. Tin, (2007) Drying with chemical reaction in cocoa beans,Drying Technology vol. 25, pp. 867-875.

xxxvi. Doymaz, (2005a.) Sun drying of figs: an experimental study,Journal of Food Engineering vol. 71, pp.403-407

xxxvii. Doymaz, (2005b) Drying characteristics and kinetics of okra,Journal of Food Engineering vol. 69, pp. $275-279$.

xxxviii. E. Akoy, D. Von Hörsten and M. Ismail, (2013) Moisture adsorption characteristics of solar-dried mango slices,International Food Research Journal, vol. 20, no.2, pp. 883 - 890.

xxxix. B. G. Nkouan, (2007) Conservation des fruits du karate (VitellariaparadoxaGaertn.) et de l'aiélé (CanariumscheweinfurthiiEngl.) : isothermes de sorption d'eau et extraction des matières grasses stockés,Thèse de doctorat, Université de Ngaoundéré.Cihan, K. Kahveci, O. Hacıhafızog lu, (2007) Modelling of intermittent drying of thin layer rough rice,'Journal of Food Engineering vol. 79, pp. 293-298.

xl. I.T. Togrul, D. Pehlivan, (2004) Modeling of thin layer drying of some fruits under open-air sun drying process,'Journal of Food Engineering vol. 65, pp. 413-425.

xli. E. K. Akpinar, Y. Bicer, (2008) Mathematical modeling of thin layer drying process of long green pepper in solar dryer and under open sun,Energy Conversion and Management vol. 49, pp. 1367-1375

xlii. M. Kashaninejad, A. Mortazavi, A. Safekordi, L.G. Tabil, (2007)Thin layer characteristics and modelling of pistachio nuts,Journal of Food Engineering, vol.78, pp. 98-108.

xliii. S. Jinap, J. Thien, , T.N. Yap, (1994) Effect of drying on acidity and volatile fatty acids content of cocoa beans,Journal of the Science of Food and Agriculture vol. 65, pp. 67-75.

xliv. B. Vijayaraj, R. Saravanan, S. Renganarayanan, (2007) Studies on thin layer drying of bagasse,'International Journal of Energy Research, vol.31, pp 422-437.

xlv. W. Senadeera, B.R. Bhandari, G. Young, B. Wijesinghe, (2003) Influence of shapes of selected vegetable materials on drying kinetics during fluidized bed drying,Journal of Food Engineering vol.58, pp. 277-283.Kaya, 0. Aydin, C. Demirtas, (2007) Drying kinetics of red delicious apple, Biosystems Engineering vol. 96, no. 4, pp. 517-524

xlvi. AmaKouakoubla Agnès Kouadio, Sadat Aw, Nogbou Emmanuel Assidjo, and Lucien Patrice Kouame, (2015) 'Etude de la qualité physico-chimique et mycologique du cacao (Theobroma cacao) produit dans les zones de Yamoussoukro et Soubre (Côte d'Ivoire) 'International Journal of Innovation and Scientific ResearchVol. 13 No. 1, pp. 330-340 